gunpowder charge, and a main charge of Tonite which is detonated by means of a time-fuse and detonator. Sound signals are used in lighthouses during foggy weather. They consist of a charge of compressed Tonite and are inserted in a revolving-wheel device which detonates thom at regular intervals by menns of a detonator inserted in them. The last experiment illustrnted the use of explosives in laboursaving by the demolition of a chimney stack. Owing to the proximity of the stack to other buildings, it had to be brought down in a definite direction. Bricks were removed from the base of the stack, leaving supporting pillars on that side of the stack towards which it was required to fall. These pillars were then bored and charged with the requisite weight of explosive.

The thanks of the Society are due to $\mathrm{Sir}$ Harry MeGown and the Directors of Nobel Industries, Itd., for their hospitality ; to the members of the Chemical Staff who acted as guides and interpreters; and, not least, to Dr. H. Hepworth for supplying the above account of the visit.

\section{CATALYSIS THROUGH AMERICAN SPECTACLES}

\section{E. F. ARMSTRONG and T. P. HILDITCH}

\section{$\mathrm{T}$} HE Committco on Contuct Catalysis of the Division of Chemistry and Chemical Technology of the American National Research Council has published its first report, written by the Chairman, Prof. W. D. Bancroft, in the form of a serial story appearing in the pages of the Journal of Industrial and Engineering Chemistry (April.July, 1922).

The subject is surveyed thoroughly and incisively, the viows of the upholders of various theories are given exhaustively and illustrated by well-chosen extracts from their published papers, and the report is enlivened by considerablo humour-a mode of treatment which may be recommended to the discreet attention of most writers of scientific literature. The Committeo states that it seemed the best thing it could do in its first report was to outline, as clearly as possible, tho present situation in regard to contact catalysis. After that, it should be a relatively simple matter to determino what to do next. One rather gathers that the result has been to discover objections to all the theories of contact catalysis at present in the field, so that "what to do next" should resolve itself into the establishment of a really satisfactory sound explanation, pleasing alike to physical chemists of all schools and also, lat us hope, to the mero chemist.

The "radiation" hypothesis fares worst: the paucity of experimental evidenco, or, rathor, tho apparent indifference of its exponents to the desirability of exporimentally, as well as hypothetically, corrolating infra-red absorption with catalytio action in as many cases as possible, is stressed, and the conclusion reached is that " it is quite extraordinary that a theory like this should get a scientific standing with apparently nothing back of it." It is, however, in regard to the treatment of the other two hypotheses-"intermediato compound" and "adsorption"-that we are tempted to join issue with the Committee, which seems very impossible to pleaso: but perhaps destructive criticism is so ensy.

The present writers' disavowal of preciso knowledge of most of the "unstablo intermediate compounds" (in the transient existenco of which they have been led to believe from a consideration of the chemical transformations in hand) is quoted in extenso, including the statement that they might well be as "indofinite " ns the adsorption of dye by fibre," and is followed by the criticism that though we believe firmly in the formation of definite intermediate compounds, our conception of an intermedinto compound is so elastio and our knowledge of the conpositions of the assumed intermedinte compounds is so limited that thero would probatuly be no difficulty in rewriting all our results in terms of adsorption.

Yet, when the latter view is considered in detail, it receives somewhat rough handling: "If we adopt Langnuir's views of oriented adsorption, all sorts of things become possible"but "such a suggestion is of very littlo value unless it can bo made definite . . . it may well be that some entirely different hypothesis will prove necessary . . . for the moment it looks as though the organic chemist were the safer man to follow . . . the identification of the intermedinte compounds does not account for the catalytic action. On the other hand, it is impossible to take the next step until the intermediate compounds bavo been identified." 'This, in sporting languago, looks like backing each theory both ways; at the same time the Committee concludes that the difference between what is meant by thoso who talk of "definite" or "indefinito intermediato compounds," and those who refor to "adsorption" is "psychological and not chemical."

The possibility of explaining cata ysis by menns of the kinotic theory of molecular collisions-tho function of a catalyst being then in some way to increase the opportunities for collisions of molecules, perhaps in specifio positions, is considered in somo dotail, but the Committee is apparently inclined to the viow that on the wholo "activation by adsorption " affords a botter explanation. The vaguoness of what is implied by "aotivation" is fully appreciated by tho Committeo, as may be scon from its reference to Baly's hypothesis on "opening up fields of force," but it seoms to feol thit Langmuir's thoory of "orionted

\footnotetext{
1 Proc. Iuy. Soc., I11:0, 88a, \$7
} 
adsorption " offers the possibility of an explanation of tho supposed activation, for the last word is a suggestion that Langmuir's theory would throw more light on tho real problem of contact catalysis if it wero developed so as to show, for example, that an ester was adsorbed in different ways by different catalytio agents, and that the reaction took placo at the point of the molecule " where the ester tied on to the adsorbent, forming the indefinite compound."

Whether this is psychological or etymological difference, it is perfectly plain that the Committee's final conclusion, the Langmuir theory of adsorption, in so far as it applies to catalysis, and our own intermediate-compound theory, all come to the samo thing. Frankly, we are tiring of etymological splitting of hairs in this matter. Organic chemists will always regard these things from their own standpoint, and so will physical chemists or puro physicists; but what we maintain is that in recent work on catalysis the "adsorption" school of physicists and tho "intermediate-compound" group of organic chemists havo developed theories which are on closely converging lines, and wo suggest that the next move is a definite acceptance of this fact by both sides, followed by mutual exchange of views to firciliate further progress. If tho organic chemist, for example, were to state frankly the details which do not at the moment fit in closely with his point of view, and mutual examination of temporarily irreconcilable data were undertaken by representatives of the chemical and physical views from their respectivo standpoints, it is more likely that progress would be resumed than if the apparently interminable discussion on terminology wero pursued further.

The reluctance of some chemists (wo had almost written catalytic chemists) to have anything to do with chemical compounds, however unstable, is hard to understand, but is well illustrated by tho Committee's failuro to grasp why, if the dehydration of alcohol by alumina depends on the intermediate formation of aluninium ethylato, kaolin should act almost as well as alumina, sinco "the formation of a definite kaolin ethylate seems improbablo." Now, surely it is common knowledgo that kaolin and the many other complox silicates and alumino-silicates, although definito in one sense, are indefinite in that various molecular proportions of the constituent oxides may bo found combined together and may act to some extent independently of the total molecule as such. 'Thus, in somo other complex silicutes, the zeolites, it is actually and readily possiblo to replace somo of the bases by others, for oxample, soda by limo, and vice versa, without affecting in any way the alumino-silicato part of tho complex. Sinco then the complox silicato moleculo is so flexiblo that part of it can be ohomically interchunged without dis. rupting the whole, it is equally possible for the alumina in kaolin to carry on transient combination with alcohol without affecting the rest of the kaolin molecule. The phenomenon of base-exchange in the zeolites is a particularly beautiful analogy of the case of intra-molecular chemical interaction which, although non-catalytic, should be borno in mind before dismissing too lightly the probability of intermediatc-compound formation during catalysis.

The action of "promoters" is dealt with briefly in the report, reference being made to Peaso and Taylor's summary of the data on this branch of the subject." Whilst quoting Rideal and Taylor's supposition that the promoter alters the proportion in which the interactants aro adsorbed at the catalyst surface, the Committeo adds an alternative suggestion, namely, that perhaps the catalytic agent activates only one of the reacting substances or activates one chiefly, whilst the promoter activates or increases the activity of the other. The subject of promoter action is, however, so complicated and obscure that a considerable amount of further detailed experimental work is necessary before a general explanation is likely to be discovered. It is shown that the theory of poisoning of contact catalytic agents has been more satisfactorily developed. Any substance which retards, or prevents, the approach of the reacting sub. stances to the catalytic agent will slow down or put an end to the reaction; or, the poisoning of a catalytic agent is due to marked adsorption, which cuts down the adsorption of the reacting suibstances.

The recent work of Taylor and Burns, 3 of Maxted,' and of others is fully discussed and the evidence for the above views concisely summarised. An interesting point is mado when it is remarked that " poisoning " of noncatalytic reactions is a fimiliar phenomenon in the non-corrosion of many oxidisable metals due to a minute protective filui of oxide. In this connexion wo would draw attention to tho unfortunato manner in which physicochemical theory lags behind technical practice in the realm of catalytic action. It is no secret that, as in other technical applications of catalysis, the matter of "poisons" was one of tho greatest difficulties connected with fathydrogenation. These dilficulties were overcomo in works' practice ton years ago mainly by consideration of the possibility of "films" of various kinds preventing contact between catalyst, oil and hydrogen, although the blessed word " adsorption " was not specifically invoked, oven though it had by that time been invented.

Rosenmund's" employment of suitable "poisons" to modify tho action of catalysts

J. Jliys. Chem., 1020, 24, 241

I Jisuted, J. Chom. Soc., 10 io, 115, 1050; 1920, 117, 1280, 1601 ; 1021, Maxted,

1021, 119,225 Hor., 1021, 642, 435, 638, 1002 
is referred to, and this seems to be a ficld of which the potentialities are by no means yet fully cxplained.

Other subjects which are dealt with are the mixed oxidation catalysts devised by Lamb, Bray and Frazer," Rideal's attempted connexion between overvoltage and catalytic power, $i$ and the apparent stimulation of some catalytic hydrogenations by small quantities of oxygen."

Whilst the report gives a very full account of the present knowledge of the procedure of contact catalysis, we feel that the lines on which

\author{
- J. Ind. Ens. Chem., 1020, 12, 217 \\ TJ. Amer. Chem. Soc., 1920, 42, 0 \\ - Willstatter \& Waldeschmldt-Ieltz., Ber., 1821, 54, 113
}

further work is apparently recommended to be undertaken are somewhat restricted in scope. In our opinion more attention should be paid to the characteristic side actions which proceed during most cases of catalysis.

Although we have handled the report critically, we do not wish in any way to detract from its great value at the present juncture. The more fully and frankly such problems are discussed the better for chemical progress ; all hypotheses aro of value provided they are put to the test of experiment and even in catalysis an ounce of practice is worth a great deal of theory. The thanks of all chemists are due to Prof. Bancroft and his colleagues for tho labour they have expended on their report.

\section{ASSOCIATION OF BRITISH CHEMICAL MANUFACTURERS}

$\mathbf{T}$

11E sixth annual report of the Association covers tho most diflicult period, from tho trade point of view, which las yet been experienced; but, despite the adverse circumstances, the Association has firmly maintained its numerical strength, improved its finances, and established its position.

For the tirst time in the history of the Industry a thoroughly representativo chemical exhibition was organised by the Association as a section of the British Industries lair, held at the White City early in 1922. The exhibition created great interest, both in trade and oflicial circles, about fifty menbers of the Association participated, and although, as was to be expected, they were not overwhelmed with orders, a certain amount of business was done; the real value of the exhibition lay in tho education of the public mind as to the scope and posoibilities inherent in British chemical industry.

The revision of the Association's Directory has proved to be more complicated and dificult than was anticipated. The Russian and Japaneso languages have been replaced by German, and the lists of products and proprietary trado names have been extended. Tho publication should bo ready for distribution at an early date. During the year the Association's painphlet on "British Resenrch Chemicals" was revised and greatly enlarged to cover about 1800 fine-chemical products, including inorganic chemicals, indicators, and microscopjc stains; many thousand copies vere distributed to chemists, 'I'rade Commissioners and others interested, in all parts of the world. Information concerning the industry has been contributed to the l'ress throughout the year, and the public has been lept informed of the progress of the industry.

The Council, having felt that the time had como when an effort should bo mado to get tho terms of contracts with public authorities so amended ns to lio just and reasonable to both the contracting parties, appronched tho Federation of British Industries, and this body has set up a committeo for the purpose of revising the conditions of forms of contract, tender and specifications in uso by'
Government departmento, municipalities and other public bodies. Mr. H. liergusson represents the - Assuciation on this Committeo.

Since tho conclusion of the war many countries have revised their customs tariffs, and thoso of Spain and tho United States have in particular engaged tho attention of tho Conncil. Mr. R. G. Porry has represented tho Ascociation on the advisury board nominated by the Federation of British Industries to assist tho Bonrd of 'Irade in its negotiations with the Spanish Government.

IIuch useful work has been carried out by the Joint Research Committee of the Association and the British Chemical Plnnt Manufacturers' Association, and an undorstanding has been reached with tho British Hengineering Standards Association whereby overlapping of activities will bo avoided; the latter Associntion has issued a Directory, which supplies a long-felt want. The report on the Standardisation of Steam-Jacketed Pans (c). J., 1922, 52 18) aroused great interest throughont the industry, and its excellence is shown by the adoption of the specification by tho British Engincering Standards Association as tho official British standard. A similar report on standard covers for jacketed pans will bo issued shortly. Preliminary reports on the standardisation of castiron filter-presses liave been issued for criticism (cf. J., 1021, $401 \mathrm{n}, 1922,210 \mathrm{n}$ ), and the final report is nearly ready for publication. 'The use of nickel, Monel metal and chromiun steel in chomical plant has been investigated.

The Association has taken a sympathetic interest in the inauguration of the Institution of Chemical Engineors, of which the General Manager is vicechairman. 'This new organisation should bo of considerablo benofit both to chemicnl and plant manufacturers.

Throughout the year the Council has beon constantly ongaged on the problem of transport. Tho lRiilways Bill, which received tho Royal Assont in August, 1021, is of great importance to tho chomical inclustry in that, for the first timo in the history of rnilways; it takes awny from tho railway 